\title{
Separation of Quisqualate- and Kainate-Selective Glutamate Receptors in Cultured Neurons from the Rat Superior Colliculus
}

\author{
M. Perouansky and R. Grantyn \\ Department of Neurophysiology, Max Planck Institute for Psychiatry, 8033 Martinsried, Federal Republic of Germany
}

The aim of the present study was to identify and characterize the receptors and ionic channels mediating the compound response of tectal neurons to exogenous L-glutamate (Glu). Particular attention was paid to the question of whether separate receptors and channels exist for quisqualate (QA) and kainate (KA) and, if so, whether binding to one of these receptors would modify the response elicited through the other.

Neurons were dissociated from the superficial gray layer of the superior colliculus from E21 or P1 rats. Between days 14 and 21 in vitro, responsiveness of tectal neurons to Glu and related substances was tested by recording the wholecell currents induced by rapid superfusion with drug-containing salt solutions.

Our experiments showed that tectal neurons express at least 3 distinct types of receptors for acidic amino acids. KA-activated currents $\left(I_{(K \mathrm{~A})}\right)$ differ from QA-activated currents $\left(I_{(\mathrm{OA})}\right)$ in their dose-response characteristics, desensitization patterns, selective blockade with kynurenic acid and suppression by elevated $\left[\mathrm{Ca}^{2+}\right]_{0} I_{(\mathrm{KA})}$, but not $I_{(\mathrm{OA})}$, is significantly reduced by low levels of $\left[\mathrm{Cl}^{-}\right]_{0}$, and the $\left[\mathrm{Cl}^{-}\right]_{0}$-dependent shift of the reversal potential for $I_{(\mathrm{KA})}$ suggests that KA promotes a conductance decrease for $\mathrm{Cl}^{-}$. Such an effect has been ascribed to APB-receptors, but L-2-amino-4-phosphonobutyrate (APB) Itself failed to induce current responses in tectal neurons. KA was without effect when administered together, and in equimolar concentrations, with QA. The block of $I_{(\mathrm{KA})}$ was, however, surmounted by applying KA at considerably higher concentrations. It is concluded that $Q A$ acts as a low-affinity competitive antagonist at the KA site and as a high-affinity agonist at its own receptor. The response to the endogenous ligand Glu reflects properties of all receptors. QA and KA receptors account for 20$30 \%$ (QA) and $49-82 \%$ (KA) of the compound current elicited with $100 \mu \mathrm{M}$ Glu. These results indicate that binding of Glu does not, in contrast to $Q A$, produce any significant suppression of the KA-receptor-mediated current component.

The density of binding sites for L-glutamate (Glu) is known to be high in the superficial gray layer of the mammalian superior colliculus (SC) (Greenamyre et al., 1984; Monaghan and Cot-

\footnotetext{
Received Jan. 19, 1988; revised May 4, 1988; accepted May 27, 1988.

We wish to thank Drs. Hans-Dieter Lux and Terrance Egan for reading the manuscript and providing many helpful comments. We are grateful to Mrs. Christine Pfitzner for excellent technical assistance.

Correspondence should be addressed to Dr. Rosemarie Grantyn, Department of Neurophysiology, Max Planck Institute for Psychiatry, Am Klopferspitz 18A 8033 Martinsried, FRG.

Copyright (c) 1989 Society for Neuroscience $0270-6474 / 89 / 010070-11 \$ 02.00 / 0$
}

man, 1985), but it has not been clarified to what extent particular acidic amino acid receptors (AARs) may contribute to glutamatergic synaptic transmission in this area. Moreover, the physiological effects of endogenous and exogenous acidic amino acids have remained unexplored. A tissue culture preparation of SC would provide a suitable means of addressing such issues, since neurons obtained from the target area of glutamatergic visual afferents (Fosse et al., 1986; Anderson et al., 1987) can be isolated, maintained in culture, and submitted to patch-clamp recording (Grantyn et al., 1987). A previous paper dealt with the $N$-methyl-D-aspartate (NMDA)-selective subclass of AARs and its link to a proton site that activates a transient $\mathrm{Na}^{+}$current (Grantyn and Lux, 1988). Here, we ask the following: Which of the previously described non-NMDA receptors are expressed by cultured neurons from the superficial gray layer? By analyzing the current responses to established Glu agonists, we hoped to reveal receptor and channel properties that could then be used to cstimate the specific function of quisqualate (QA)-, kainate (KA)-, or L-2-amino-4-phosphonobutyrate (APB)-selective receptors in visual signal transmission.

Four AAR subtypes (A1-A4) have been distinguished by the selective capacity of NMDA, QA, KA, and APB to displace Glu from $\mathrm{Na}^{+}$-insensitive binding sites on synaptic membranes (Foster and Fagg, 1984; Mayer and Westbrook, 1987). The validity of this classification scheme is supported by peculiarities of receptor distribution (Monaghan et al., 1983; Greenamyre et al., 1984; Olson et al., 1987; Represa et al., 1987), differences in ionic requirements for ligand binding (Beaumont et al., 1979; Honoré et al., 1982; Fagg et al., 1983; Fagg and Lanthorn, 1985), neuropharmacological profiles (Biscoe et al., 1976; McLennan and Lodge, 1979; Davies and Watkins, 1981; Anis et al., 1983; Davies and Watkins, 1985; Huettner and Baughman, 1986; Miljkovic and MacDonald, 1986; Wong et al., 1986), and second-messenger effects (Sladeczek et al., 1985; Baudry et al., 1986; Nicoletti et al., 1986; McCaslin and Morgan, 1987; Novelli et al., 1987; Sugiyama et al., 1987).

As for electrophysiological studies, recent research has largely focused on NMDA receptors since reliable tools are available for identification of NMDA-activated receptors and channels (see Ascher and Nowak, 1987; Kemp et al., 1987; MacDermott and Dale, 1987; Mayer and Westbrook, 1987, for recent reviews). A physiological action of APB was demonstrated in Onbipolar cells of the mudpuppy retina, where this Glu agonist suppressed the response to light and induced hyperpolarization (Slaughter and Miller, 1981), possibly by decreasing a Cl- conductance (Miller and Dacheux, 1976). However, APB-induced conductance changes have not yet been explored with voltageclamp methods. In fact, it seems questionable that mammalian central neurons express synaptic APB receptors (Kessler et al., 

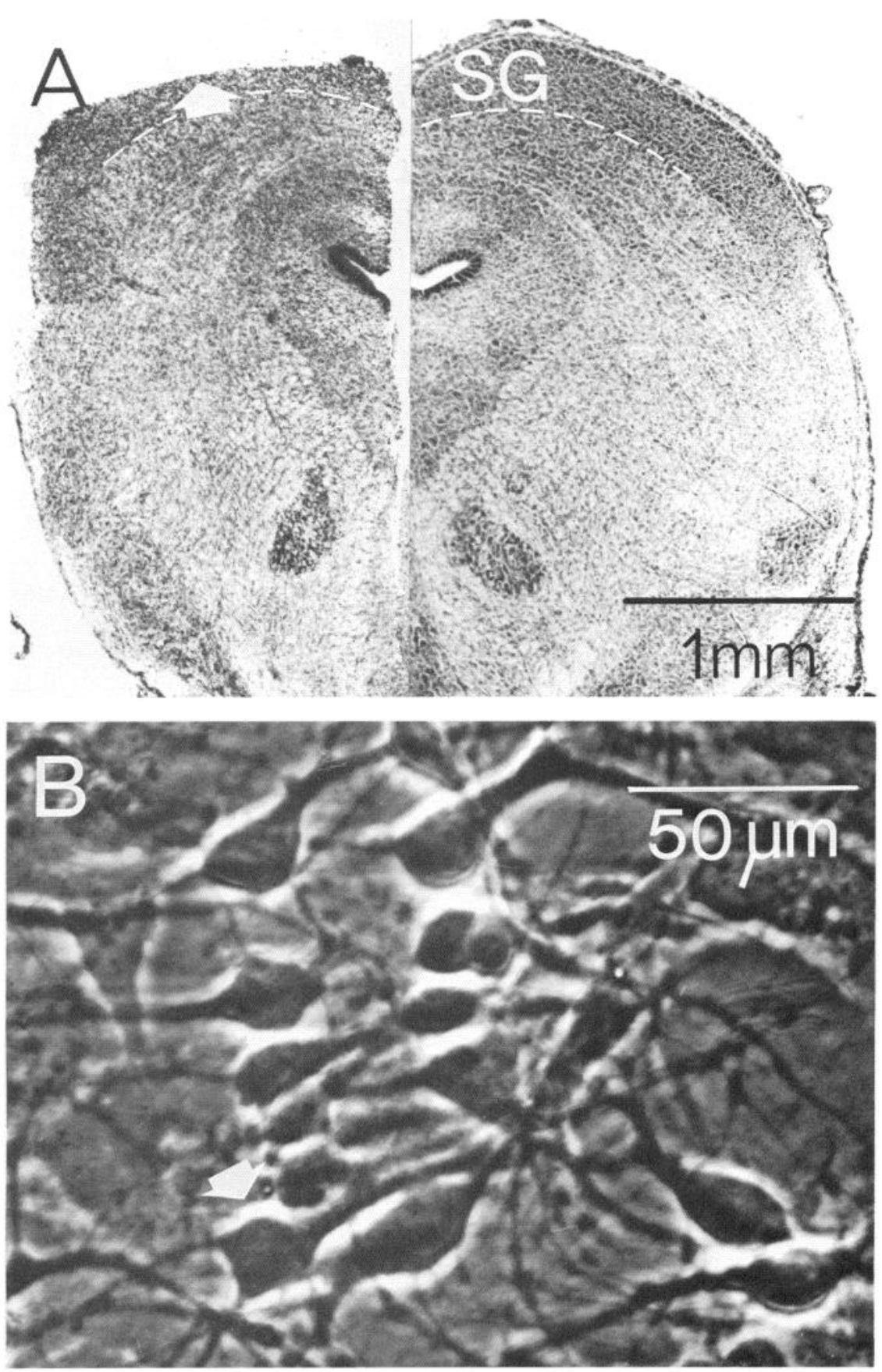

Figure 1. Photomicrographs showing the superficial gray layer $(S G)$ of rat superior colliculus and a dissociated cell culture derived from this layer. $A$, Frontal section through the mesencephalon of an E21 rat fetus. Staining with toluidine blue. Arrowhead indicates the level of cut. $B$, Dissociated cell culture after 2 weeks in vitro.
$1987 \mathrm{a}, \mathrm{b})$. Binding of QA or KA is signaled by activation of a mixed cationic conductance (Mayer and Westbrook, 1984; Ishida and Neyton, 1985; Hals et al., 1986; Kiskin et al., 1986; Vlachová et al., 1987). Thus far, it has proved to be difficult to separate QA- and KA-activated conductance changes, although single-channel studies with QA and KA application (Cull-Candy and Usowicz, 1987; Jahr and Stevens, 1987) revealed differences in the average level of unitary conductance (higher with QA) and probability of channel opening (higher with KA). The latter observations support the belief that electrophysiological criteria may eventually be established to distinguish QA- from KAreceptor mediated effects and to assess the contribution made by each of these receptors to the compound response elicited by exogenous and endogenous acidic amino acids.

\section{Materials and Methods}

Dissection and culture. Superior colliculi were dissected from the brains of 21-d-old rat fetuses or P1 postnatal rat pups and collected in cooled calcium/magnesium-free balanced salt solution with Hanks' salts (HBSS). At this age, the superficial gray layer of the rat SC has a depth of 330$350 \mu \mathrm{m}$ and distinct margins. Care was taken to place the cut within the confines of this layer, removing tissue pieces of $200-300 \mu$ m thick only. Histological examination verified the correctness of the dissection (Fig. 1A).

The tissue was incubated for $15 \mathrm{~min}$ at room temperature in a solution of $1 \%$ trypsin with $0.5 \%$ deoxyribonuclease (Worthington) in HBSS, washed 3 times with HBSS, and transferred into a solution of $0.1 \%$ DNAse in HEPES-buffered minimum essential medium with Hanks' salts (MEM-HEPES). Cells were dissociated by passage through a series of siliconized Pasteur pipettes with fire-polished narrowed tips, centrifuged $(10 \mathrm{~min}$ at $65 \times \mathrm{g})$, and resuspended and grown in MEM-bicar- 
A

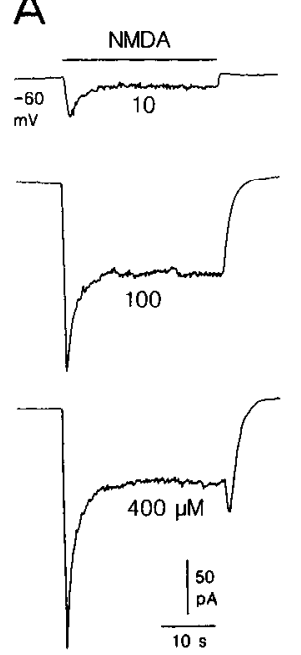

B
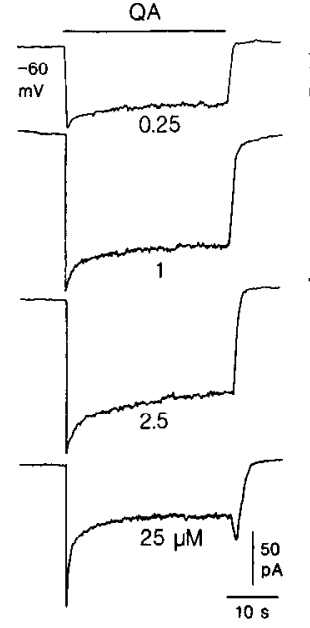

C

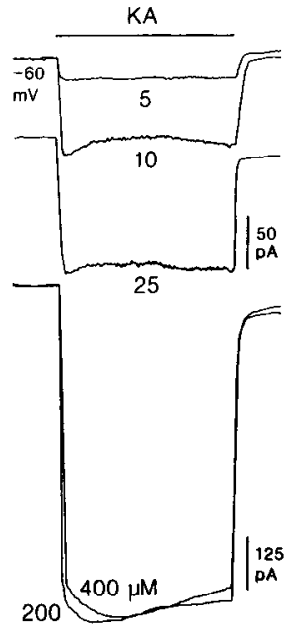

Figure 2. Current responses to receptor-selective Glu agonists. Response to NMDA $(A), \mathrm{QA}(B)$, and $\mathrm{KA}(C)$ at indicated concentrations. Bar marks the period of agonist application. At left of each upper trace, holding voltage $\left(V_{h}\right)$. Recordings from 3 different neurons. Standard solutions, except $A$, where $\mathrm{Mg}^{2+}$ was omitted.

bonate supplemented with $5 \%$ horse serum and $5 \%$ fetal calf serum (Gibco). Plastic dishes, $35 \mathrm{~mm}$ (Nunclon), were coated with a mixture of $0.05 \%$ collagen obtained from calf skin (Sigma Type III) and $0.002 \%$ poly (D-lysine) (Sigma). A glass ring was inserted in the center of each dish, and the cells placed inside the ring area of about $1 \mathrm{~cm}^{2}$. The plating density was generally not less than $200,000 \mathrm{cells} / \mathrm{cm}^{2}$. Neurons grew on top of a confluent glial layer in humified air containing $5 \% \mathrm{CO}_{2}$ at $37^{\circ} \mathrm{C}$ (Fig. 1B). Glial mitosis was controlled by addition of cytosine- $\beta$-Darabinofuranoside (Sigma) at a concentration of $10^{-5} \mathrm{M}$ for $12 \mathrm{hr}$ on the 4th or 5th day in vitro (div). The life span of these high-density mixed cultures ranged from 3 to 6 weeks. GAD immunohistochemistry (S. Warton and R. Grantyn, unpublished observations) indicated that in cultures obtained from E2I rat embryos GAD-positive neurons constitute about $35 \%$ of the total cell population. They form extensive terminal networks that release GABA from div 2 on. Therefore, TTX $(1 \mu \mathrm{M})$ and bicuculline methiodide $(100 \mu \mathrm{M})$ were added to suppress synaptic activity during the experiments.

Electrophysiological recordings. Glass micropipettes were prepared from thin-walled Duran glass (Schott Ruhrglas, Main, FRG) following the procedure of Hamill et al. (1981). Electrodes were coated with Sylgard (Dow Corning, Seneffe, Belgium) and had resistances of about $10^{7}$ $\Omega$. They were filled with a standard solution containing (in $\mathrm{mm}$ ): $N$-methylglucamine, 120; TEA-Cl, 20; EGTA, $8 ; \mathrm{MgCl}_{2}, 1.0 ; \mathrm{CaCl}_{2}, 0.2$; glucose, 10; HEPES, 10; ATP, 2; cAMP, 0.25. This composition of the internal solution has several advantages. First, $N$-methylglucamine penetrates very little through Glu-activated channels. Second, the absence of potassium and the addition of TEA-Cl ensures complete block of $\mathrm{K}^{+}$ conductances. Third, the presence of EGTA, ATP, and cAMP reduces the run-down of voltage- and transmitter-activated currents. However, as compared with other commonly used internal solutions, our standard intra- and extracellular solutions rendered reversal potentials for $I_{(\mathrm{OA})}$ and $I_{(\mathrm{KA})}$ more positive. In some cases, $60 \mathrm{~mm} \mathrm{NaCl}$ or $120 \mathrm{~mm} \mathrm{CsCl}$ were therefore added at the expense of $N$-methylglucamine to reverse $I_{(\mathrm{OA})}$ and $I_{(\mathrm{KA})}$ within a more negative range of membrane voltages (Figs. $7 C, 10 C)$.

Whole-cell membrane currents were recorded using an amplifier equipped with a $10^{10} \Omega$ feedback resistor (Meyer and Renz, Munich, FRG). Data were stored al $5 \mathrm{kH} /$ on a FM tape recorder (Racal) and displayed on a chart-recorder (Rikadenki), usually at a speed of $2.5 \mathrm{~mm} /$ sec.

Superfusion system and solutions. After removal of culture dishes from the incubator, the growth medium was changed for a standard salt solution containing (in $\mathrm{mM}$ ): $\mathrm{NaCl}, 120 ; \mathrm{KCl}, 3 ; \mathrm{CaCl}_{2}, 1.5 ; \mathrm{MgCl}_{2}, 1$; glucose, 10 ; sucrose, 7.5; HEPES, 10, $\mathrm{pH}$ 7.3. In some experiments, $\mathrm{Na}^{+}$ was replaced by $N$-methylglucamine or choline, and $\mathrm{Cl}^{-}$by isethionate
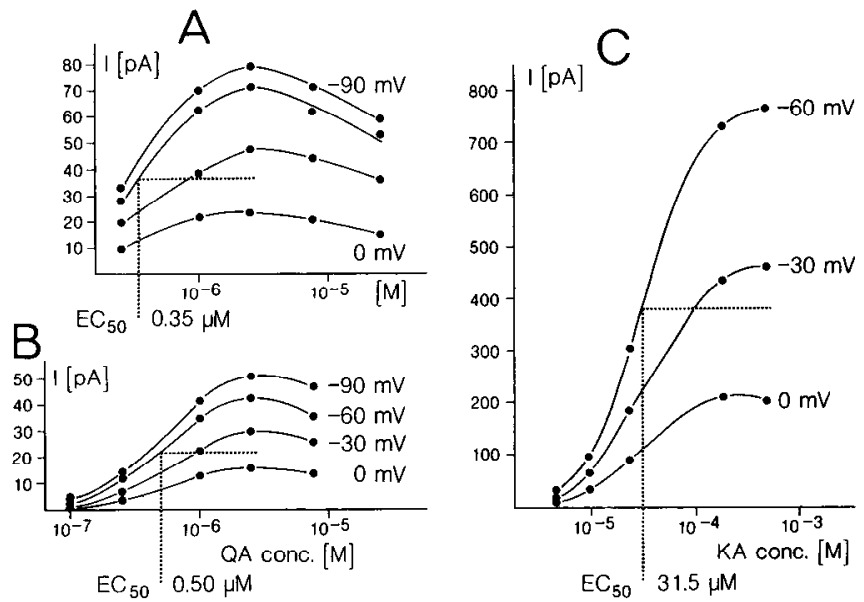

Figure 3. Dose-response characteristics for $I_{(\mathrm{OA})}(A, B)$ and $I_{(\mathrm{KA})}(C)$. Current amplitudes were measured $20 \mathrm{sec}$ after start of application and plotted against agonist concentration. In $A-C$, data points are from 3 different neurons. $V_{h}$ indicated at the right of each curve. Curves fit freehand.

or gluconate. Osmolarity was balanced with sucrose. All solutions were applied at a $\mathrm{pH}$ of 7.3 and a temperature of $22^{\circ} \mathrm{C}$. Individual dishes were not used for more than $2 \mathrm{hr}$. Cells chosen for recording were maintained under continuous flow of standard or test solutions. This arrangement minimized access of unidentified substances that might be released by the culture itself. All test solutions were freshly prepared by dissolving the appropriate amount of amino acids and their antagonists in the standard salt solution. In the NMDA-containing solution, $\mathbf{M g}^{2+}$ was omitted. All results apply to NMDA in the absence of added glycine. In experiments with various concentrations of $\mathrm{Na}^{+}, \mathrm{Ca}^{2+}$, or $\mathrm{Cl}^{-}$, a stock solution was prepared to have exactly the same amount of agonist in each barrel. A fast-switch 6 -barrel superfusion system allowed for rapid exchange of fluids via a common outflow pipette (see Konnerth et al., 1987). The exchange time was very reproducible and fell within the range of $100-150 \mathrm{msec}$. The pipette ( $200 \mu \mathrm{m}$ diameter) was placed about $100 \mu \mathrm{m}$ from the voltage-clamped neuron. Less ramified cells with soma diameters of about $20 \mu \mathrm{m}$ were chosen for recording (Fig. $1 B$ ).

NMDA $(10-400 \mu \mathrm{M})$, QA $(0.1-200 \mu \mathrm{M})$, KA $(1-400 \mu \mathrm{M})$, and APB $(1-100 \mu \mathrm{M})$ were applied in a stepwise manner for a period of $30 \mathrm{sec}$ at a frequency below per $2 \mathrm{~min}$. As a rule, currents were recorded at holding voltages $\left(V_{h}\right)$ between -90 and $+30 \mathrm{mV}$. We tested a total of 130 neurons. Thirty of these were exposed to both QA and KA. To avoid variability in results, cultures were used for electrophysiological measurements during one week only, between div 14 and 21 .

\section{Results}

\section{Current responses to different Glu agonists}

All tectal neurons were found to be responsive to NMDA, QA, and $\mathrm{KA}$; no cells responded to APB. To facilitate comparison of the current responses to the effective agonists, representative examples are presented together in Figure 2. In this paper we shall consider the responses to QA and KA only. The currents elicited by these agonists differ in time course and amplitude (Fig. 2, $B, C$ ). With higher agonist concentrations, $I_{(\mathrm{QA})}$ had a biphasic configuration, while $I_{(\mathrm{KA})}$ remained steady throughout the application period. The maximal amplitudes of $I_{(\mathrm{KA})}$ exceeded the maximal amplitudes of $I_{(\mathrm{QA})}$ by about 10 times. Nonetheless, the noise increase was often smaller during application of KA (see also Fig. 4).

Prolonged application of high agonist concentrations and large amplitudes of $I_{(\mathrm{QA})}$ and $I_{(\mathrm{KA})}$ could lead to secondary effects causing an Off-response. The present study did not aim at identifying 


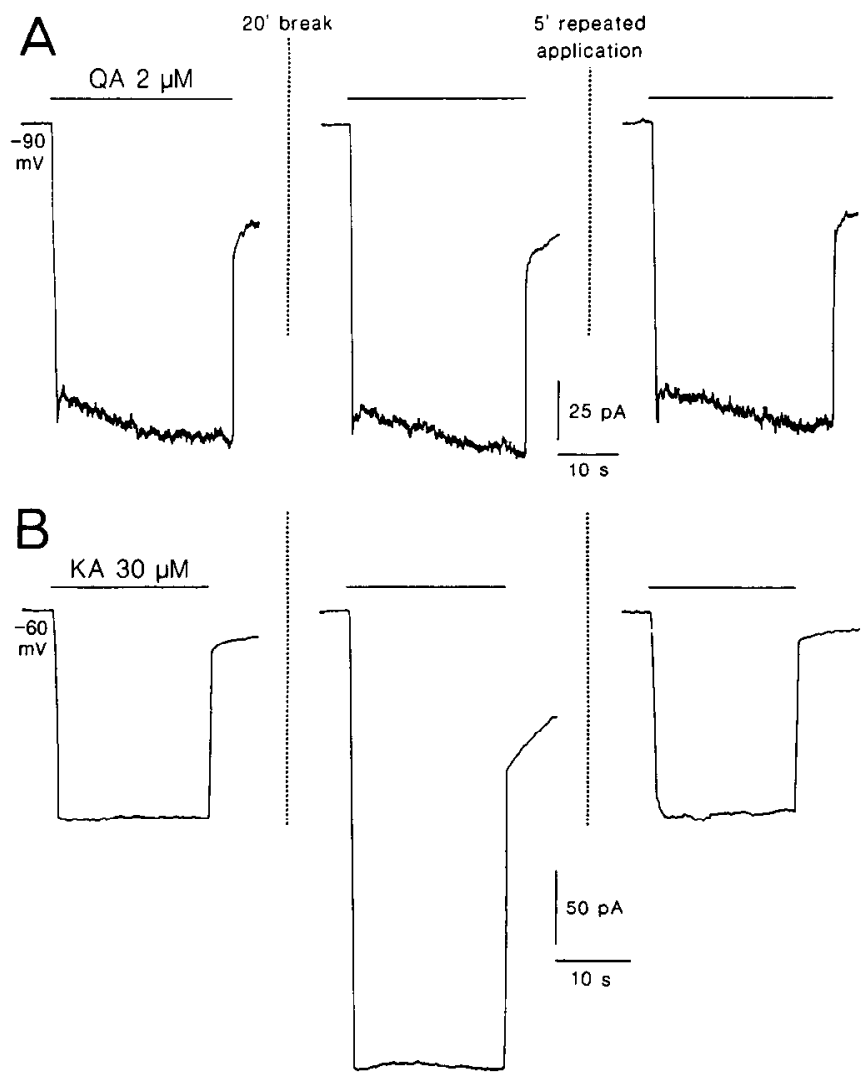

Figure 4. Recovery of $I_{(\mathrm{KA})}(B)$ but not $I_{(\mathrm{QA})}(A)$ when a regular application cycle (per $2 \mathrm{~min}$ ) was interrupted for $20 \mathrm{~min}$.

the probably complex nature of the aftercurrents, which were particularly prominent following large $I_{(\mathrm{KA})}$ (Fig. $4 B$, middle trace). In any case, the aftercurrents did not result from incomplete wash-out of the agonist.

Concentration and time dependence of $\mathrm{I}_{(Q A)}$ and $\mathrm{I}_{(K A)}$

Figure 3 presents the dose-response curves for $I_{(\mathrm{QA})}(A, B)$ and $I_{\text {(KA) }}(C)$. In each experiment $(n=10)$, one and the same cell was exposed to 5 different agonist concentrations. The concentrations of QA required to activate and to saturate the current were much lower than those of KA. Half-effective concentrations $\left(\mathrm{EC}_{50}\right)$ ranged from 0.25 to $0.65 \mu \mathrm{M}$ for $\mathrm{QA}$ and from 26 to $33 \mu \mathrm{M}$ for $\mathrm{KA}$, the respective averages being 0.5 and $30 \mu \mathrm{M}$. These estimates apply to current amplitudes measured $20 \mathrm{sec}$ after the start of agonist application. The $\mathrm{EC}_{50}$ for the peak of QA-activated currents were, on average, lower than those for the steady state (range, $0.1-0.31 \mu \mathrm{M}$ ). The decrease of $I_{(\mathrm{QA})}$ with concentrations above $2.5 \mu \mathrm{M}$ reflects the stronger attenuation of the plateau compared with the peak current (Fig. 2B). Such behavior is indicative of receptor "desensitization" (Katz and Thesleff, 1957; Magazanik and Vyskočil, 1973; Dudel, 1975; Feltz and Trautman, 1982).

In agreement with previous studies on other central neurons (Ishida and Neyton, 1985; Kiskin et al., 1986; Vyklický et al., 1986), KA responses were little affected by a concentration increase beyond the dose giving maximal current amplitudes. However, regular repetition suppressed $I_{(\mathrm{KA})}$ even more than $I_{(\mathrm{QA})}$. Figure $4 B$ shows that a break of $20 \mathrm{~min}$ and subsequent regular repetitions could lead to pronounced changes in the amplitude of $I_{(\mathrm{KA})}$, whereas $I_{(\mathrm{QA})}$ remained stable throughout the
A

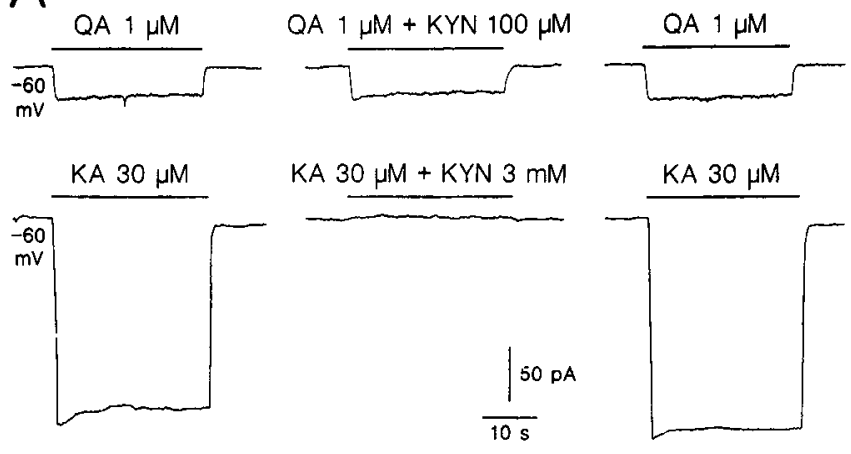

B
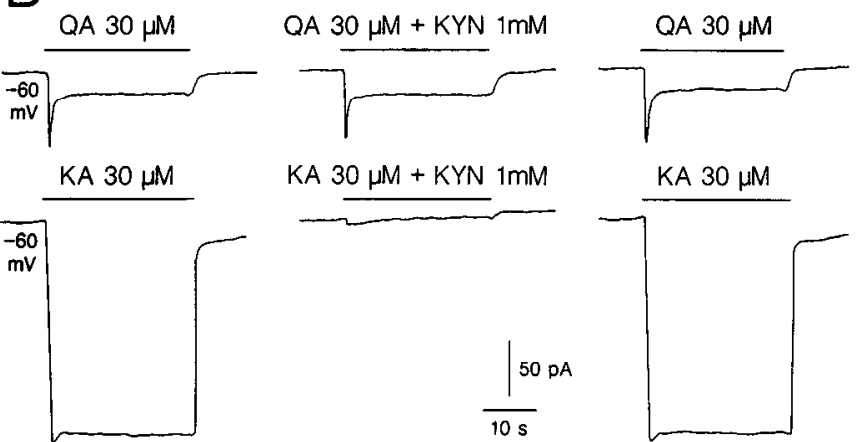

Figure 5. Effects of KYN using equieffective $(A)$ and equimolar $(B)$ concentrations of QA and KA. In each experiment, QA- and KA-containing control and test solutions were prepared to contain the same amount of drug. $A$ and $B$, Records from 2 different neurons. Experiments in $10 \mu \mathrm{M}$ APV. Note block of $I_{(\mathrm{KA})}$ but not $I_{(\mathrm{QA})}$.

recording period (Fig. $4 A$ ). These results may reflect agonistdependent differences in the time course of desensitization. Since many applications were necessary to complete an experiment, we decided to ignore the first responses to KA and to avoid longer interruptions in the application cycle.

\section{Action of Glu antagonists}

We intended to determine whether separate receptors account for the contrasting effects of QA and KA by using receptorselective antagonists. In trying a number of known Glu antagonists, we found that, in tectal neurons, kynurenic acid (KYN) was a very selective and potent antagonist of KA, when NMDA receptors were blocked with $\mathrm{D}$-2-amino-5-phosphonovaleric acid (APV) (Evans et al., 1982) or $\mathrm{Mg}^{2+}$ (Mayer et al., 1984). KYN blocked also $I_{\text {(NMDA) }}$ when this current was expressed in the absence of APV or $\mathrm{Mg}^{2+}$ (Fig. 12D), as described by others (Ganong et al., 1983; Elmslie and Yoshikami, 1985; Coleman and Miller, 1986; Huettner and Baughman, 1986). Figure 5 illustrates an experiment where KYN (in the presence of APV) blocked $I_{(\mathrm{KA})}$ without reducing $I_{(\mathrm{QA})}$. The blocking action of KYN was accomplished at concentrations as low as 30 times the $\mathrm{EC}_{50}$ for $\mathrm{KA}$, whereas $I_{(\mathrm{QA})}$ remained unaffected by up to 200 times the average $\mathrm{EC}_{50}$ for QA. KYN was selective if used at equieffective (Fig. $5 A$ ) or equimolar (Fig. $5 B$ ) concentrations of QA and KA. Other established Glu antagonists turned out to be less potent. The results of tests with $\gamma$-D-glutamylaminomethylsulfonic acid (GAMS), $\gamma$-D-glutamylglycine ( $\gamma$-DGG), and glutamic acid diethylester (GDEE) are summarized in Table 1. GAMS and $\gamma$-DGG were found to be selective antagonists for KA, and GDEE a selective but very weak antagonist for QA. We conclude 
A
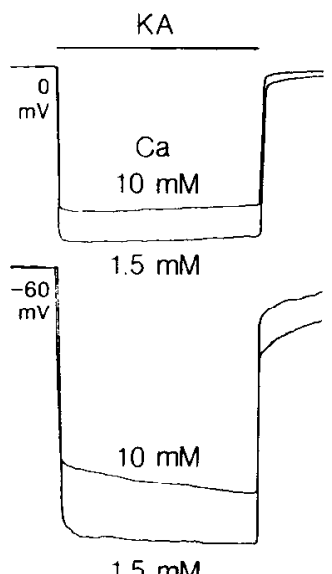

$\uparrow .5 \mathrm{mM}$
B
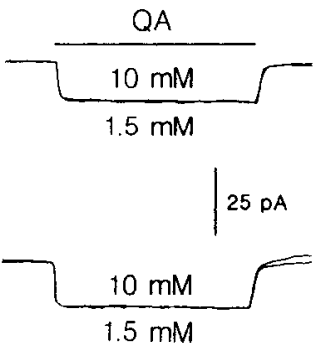

Figure 6. Effect of elevated $\left[\mathrm{Ca}^{2+}\right]_{\mathrm{O}}$ on $I_{(\mathrm{KA})}$ and $I_{\mathrm{(QA})}$. Experiments with $30 \mu \mathrm{M}$ $\mathrm{KA}(A)$ and $1 \mu \mathrm{M} \mathrm{QA}(B, C)$. Note that $I_{(\mathrm{OA})}$ was totally unaffected by increasing $\left[\mathrm{Ca}^{2+}\right]_{\mathrm{o}}$ up to $10 \mathrm{~mm}$. Records are from a single cell. that separate receptors for QA and KA must exist in tectal neurons to generate the conductance changes demonstrated here.

\section{$\mathrm{Na}^{+}$and $\mathrm{Ca}^{2+}$ dependence of $\mathrm{QA}$ - and $\mathrm{KA}$-activated currents}

Further support for the idea of separate QA and KA receptors comes from our experiments on the dependence of $I_{(\mathrm{QA})}$ and $I_{(\mathrm{KA})}$ on extracellular $\mathrm{Ca}^{2+}$ concentrations. Differences in the reaction of $I_{(\mathrm{QA})}$ and $I_{(\mathrm{KA})}$ to variation of $\left[\mathrm{Ca}^{2+}\right]_{\mathrm{O}}$ could be expected, since elevation of $\left[\mathrm{Ca}^{2+}\right]_{\mathrm{O}}$ has been shown to induce a marked decrease of KA but not QA binding (Beaumont et al., 1979; Monaghan et al., 1983; Honoré et al., 1986). Figure 6 illustrates that $I_{\text {(KA) }}$ was indeed more prone to reduction by higher $\left[\mathrm{Ca}^{2+}\right]_{0}$ than $I_{(\mathrm{QA})}$. However, channel block by $\mathrm{Ca}^{2+}$ and activation of a $\mathrm{Ca}^{2+}$ conductance could complicate the overall picture (Nowak and Ascher, 1985; Tachibana, 1985; Jahr and Stevens, 1987; Mayer and Westbrook, 1987). In fact, a reduction of $I_{(\mathrm{QA})}$ after increasing $\left[\mathrm{Ca}^{2+}\right]_{0}$ was observed in 4 of 10 neurons. In these cells, QA opened a $\mathrm{Ca}^{2+}$ conductance, as indicated by a $\mathrm{Ca}^{2+}$-dependent shift of $I_{(\mathrm{QA})}\left(7.8-9.1 \mathrm{mV}\right.$ by a 10 -fold increase of $\left[\mathrm{Ca}^{2+}\right]_{\mathrm{O}}$ ) (Fig. $7, A, B)$. The reversal potential for $I_{(\mathrm{QA})}$ in the remaining $6 / 10$ neurons and the reversal potential for $I_{(\mathrm{KA})}$ were unaffected by raising $\left[\mathrm{Ca}^{2+}\right]_{\mathrm{O}}$ (Fig. $7 \mathrm{C}$ ).

Changing $\left[\mathrm{Na}^{+}\right]_{\mathrm{O}}$ influenced $I_{(\mathrm{QA})}$ and $I_{(\mathrm{KA})}$ in similar ways. $\left[\mathrm{Na}^{+}\right]_{\mathrm{O}}$ was varied by substituting $N$-methylglucamine for $\mathrm{Na}^{+}$ (Fig. 8). The $\mathrm{Na}^{+}$-dependent shifts of $E_{(\mathrm{QA})}(B)$ and $E_{(\mathrm{KA})}(D)$ were nearly the same. On average, a 10 -fold decrease of $\left[\mathrm{Na}^{+}\right]_{0}$ moved $E_{\text {(QA) }} 27 \mathrm{mV}$ towards more negative voltages ( $n=5$; range, $18-$ $31 \mathrm{mV})$. The respective value for $E_{(\mathrm{KA})}$ was $27 \mathrm{mV}(n=5$; range, $23-30 \mathrm{mV}$ ). These numbers probably represent underestimates, since more positive reversal potentials would result from freehand curve fitting.

Dependence of $\mathrm{I}_{(Q A)}$ and $\mathrm{I}_{(K A)}$ on $\left[\mathrm{Cl}^{-}\right]_{o}$

Binding of $\mathrm{Q} \Lambda$ and $\mathrm{KA}$ to synaptic receptors is gencrally considered to be independent of extracellular $\mathrm{Cl}^{-}$concentrations (Foster and Fagg, 1984). On the other hand, it has been reported (Fagg et al., 1982; Mena et al., 1986) that QA acts as a potent displacer for APB at presumed extrasynaptic $\mathrm{Cl}^{-}$dependent sites which may be uptake sites for Glu (Pin et al., 1984; Fagg and Lanthorn, 1985; Bridges et al., 1986; Kessler et al., 1987a). We
Figure 7. Whole-cell $I-V$ relations and reversal potentials for $I_{(\mathrm{QA})}(A, B)$ and $I_{\text {(KA) }}(C)$ at different $\left[\mathrm{Ca}^{2+}\right]_{0}$. Standard intra- and extracellular solutions, with osmolarity balanced with sucrose. Note $\mathrm{Ca}^{2+}$-dependent change of $E_{(\mathrm{QA})}(A)$ but not $E_{\text {(KA) }}(C)$. Data points in $A$ and $B$ are fitted with linear-regression lines $(r$ $=0.995$ for $B$ ). $A$, Electrode filled with $\mathrm{N}$-methylglucamine; $C$, electrode filled with $\mathrm{N}$-methylglucamine/ $\mathrm{NaCl}$.

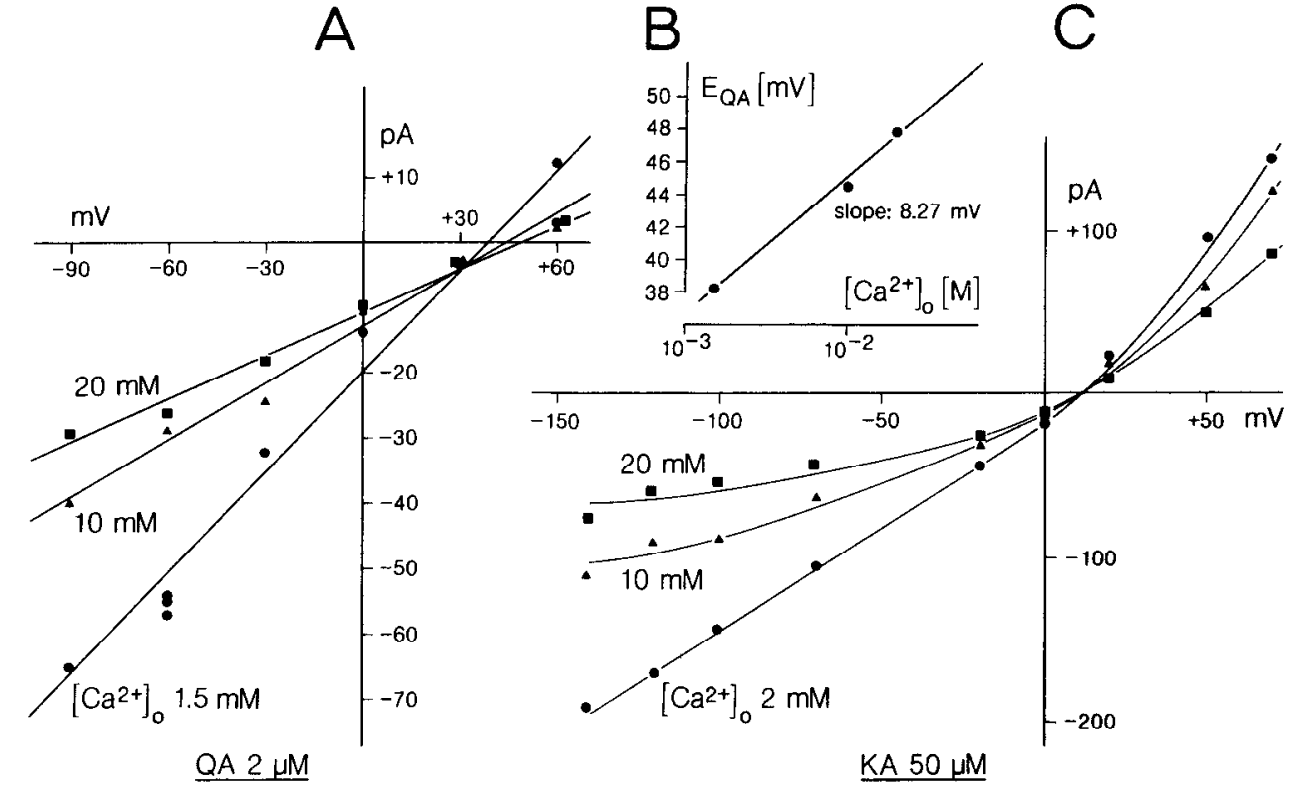



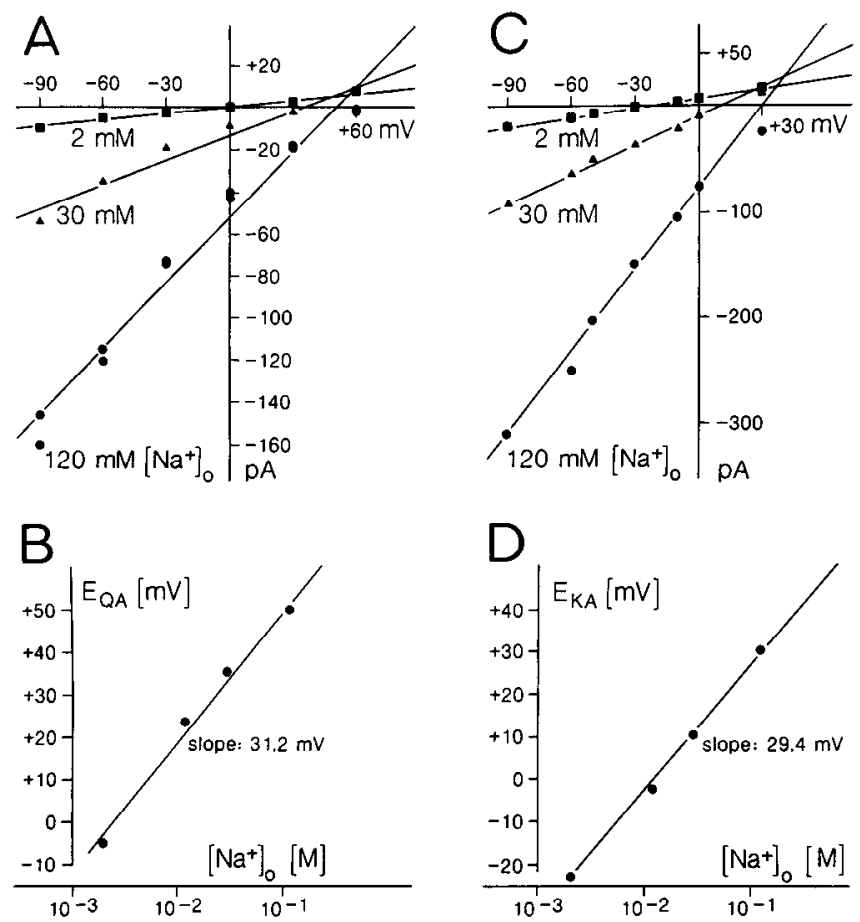

Figure 8. Whole-cell $I-V$ relations and reversal potentials for $I_{(\mathrm{OA})}(A$, $B)$ and $I_{(\mathrm{KA})}(C, D)$ at various $\left[\mathrm{Na}^{+}\right]_{\mathrm{o}}$. An intracellular solution containing $20 \mathrm{mM} \mathrm{Na}^{+}$and $100 \mathrm{~mm} \mathrm{~N}$-methylglucamine faced with different extracellular concentrations of $\mathrm{Na}^{+}$. N-methylglucamine was substituted for $\mathrm{Na}^{+}$. QA, $1 \mu \mathrm{M}(A)$, and $\mathrm{KA}, 30 \mu \mathrm{M}(C)$, in the presence of $10 \mu \mathrm{M}$ APV. Curves represent the regression lines of best fit $(r=0.999$ for $B$, $r=0.997$ for $D$ ).

found it worthwhile to reevaluate the effect of various $\left[\mathrm{Cl}^{-}\right]_{0}$ levels on both $I_{(\mathrm{KA})}$ and $I_{(\mathrm{QA})}$. $\left[\mathrm{Cl}^{-}\right]_{\mathrm{O}}$ was changed by substituting isethionate or gluconate for $\mathrm{Cl}^{-}$. Surprisingly, low $\left[\mathrm{Cl}^{-}\right]_{0}$ reduced $I_{(\mathrm{KA})}$ by up to $50 \%$ (Fig. $9, C, D$ ). The time to peak of $I_{(\mathrm{QA})}$ was prolonged, but the steady-state amplitude of $I_{(\mathrm{QA})}$ was unaffected (Fig. $9, A, B$ ).

To discriminate between the significance of $\left[\mathrm{Cl}^{-}\right]_{\mathrm{O}}$ for binding and conductance, we examined the $\mathrm{Cl}^{-}$dependence of $E_{(\mathrm{KA})}$ (Fig. $10)$. In all neurons tested $(n=14), E_{(\mathrm{KA})}$ was found to be more negative at lower $\left[\mathrm{Cl}^{-}\right]_{\mathrm{O}}$, as should be the case if a background $\mathrm{gCl}^{-}$were decreased during $\mathrm{KA}$ application. This effect was observed using either isethionate (Fig. 10A) or gluconate (Fig. $10 C$ ) as a substitute for extracellular $\mathrm{Cl}^{-}$, irrespective of whether electrodes were filled with $\mathrm{N}$-methylglucamine chloride (Fig. $10 \mathrm{~A}$ ) or $\mathrm{CsCl}$ (Fig. 10C). A 10-fold reduction of $\left[\mathrm{Cl}^{-}\right]_{\mathrm{O}}$ decreased $E_{(\mathrm{KA})}$ on average by $7.9 \mathrm{mV}$ (range, $2.3-13.8 \mathrm{mV}$ ). Twelve other
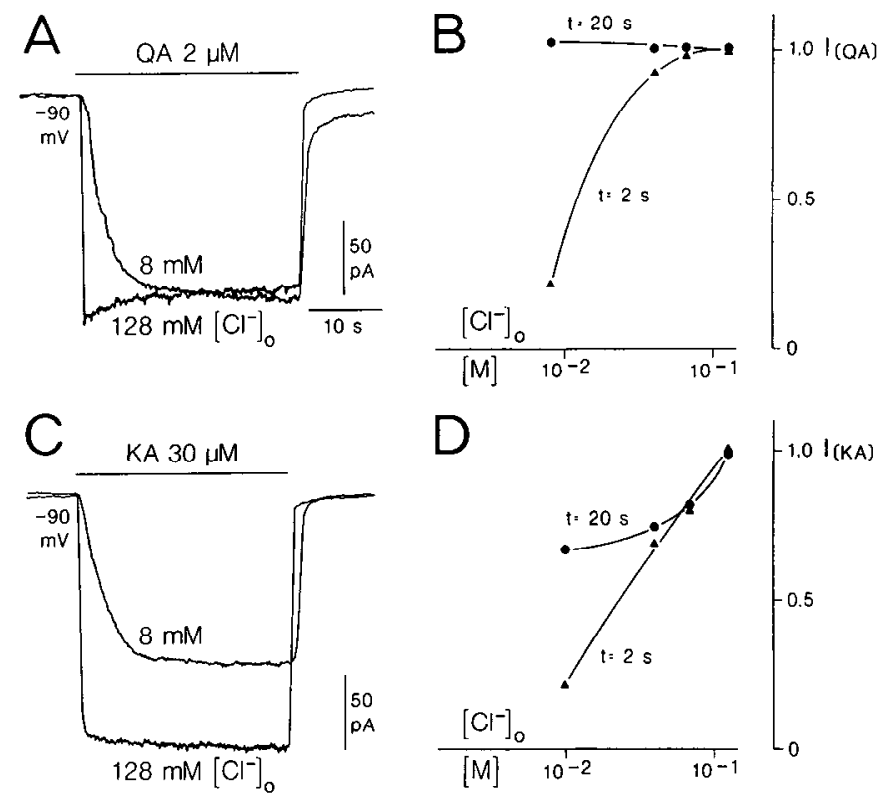

Figure 9. Effect of $\left[\mathrm{Cl}^{-}\right]_{O}$ on $I_{(\mathrm{OA})}$ and $I_{(\mathrm{KA})} . A$ and $C$, Specimen recordings. $B$ and $D$, Current amplitudes at 2 and $20 \mathrm{sec}$ after start of agonist application. Note that the steady-state amplitude (at $20 \mathrm{sec})$ is reduced in $I_{(\mathrm{KA})}$ but not $I_{(\mathrm{QA})}$.

neurons tested similarly with $2 \mu \mathrm{M} \mathrm{QA} \mathrm{did} \mathrm{not} \mathrm{display} \mathrm{the}\left[\mathrm{Cl}^{-}\right]_{\mathrm{O}^{-}}$ dependent shift of $E_{(\mathrm{QA})}$. It is interesting to note that in cells generating large $I_{(\mathrm{KA})}$, small $(10-50 \mathrm{pA})$ outward currents were seen when KA was applied logether with KYN.

This type of $\mathrm{Cl}^{-}$dependence has been discussed elsewhere only in connection with APB, which by itself did not cause any current in tectal neurons. We conclude therefore that tectal neurons may express a receptor having the characteristics of the A4 type of AAR but preferring KA to APB as a ligand. However, this leaves open the question of whether KA binding (to its own or a different site) is also dependent on $\left[\mathrm{Cl}^{-}\right]_{\mathrm{O}}$. The slowing of $I_{(\mathrm{KA})}$ in low $\left[\mathrm{Cl}^{-}\right]_{\mathrm{O}}$ suggests that this may, indeed, be the case. In experiments on 3 neurons exposed to low $(18 \mathrm{~mm}) \mathrm{Cl}^{-}$on both sides of the membrane, $I_{(\mathrm{KA})}$ was slowed and reduced by about $20 \%$ compared with the control in high $(128 \mathrm{~mm})\left[\mathrm{Cl}^{-}\right]_{\mathrm{o}}$.

\section{Simultaneous application of $Q A$ and $K A$}

To test for possible convergence of $\mathrm{QA}$ and $\mathrm{KA}$ receptors, we investigated the effect of simultaneous agonist application (Fig. 11). If the receptors and channels activated by $Q A$ and $K A$ were independent, and both ligands perfectly selective, $I_{(\mathrm{QA})}$ and $I_{(\mathrm{KA})}$

Table 1. Effects of 4 different Glu antagonists on $I_{(\mathrm{QA})}$, and $I_{(\mathrm{KA})}$

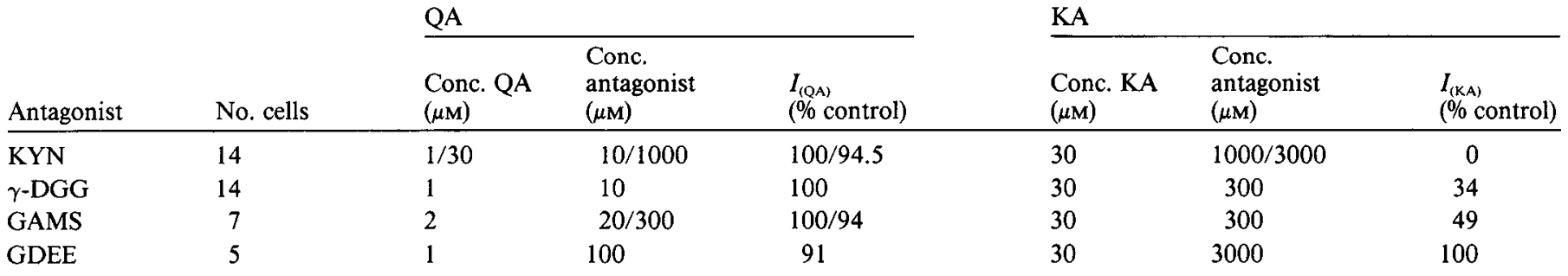

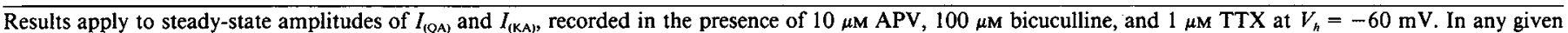
cell, effects of antagonist were tested on both $I_{(\mathrm{QA})}$ and $I_{(\mathrm{KA})}$. At the indicated concentrations, antagonists did not elicit currents by themselves. 

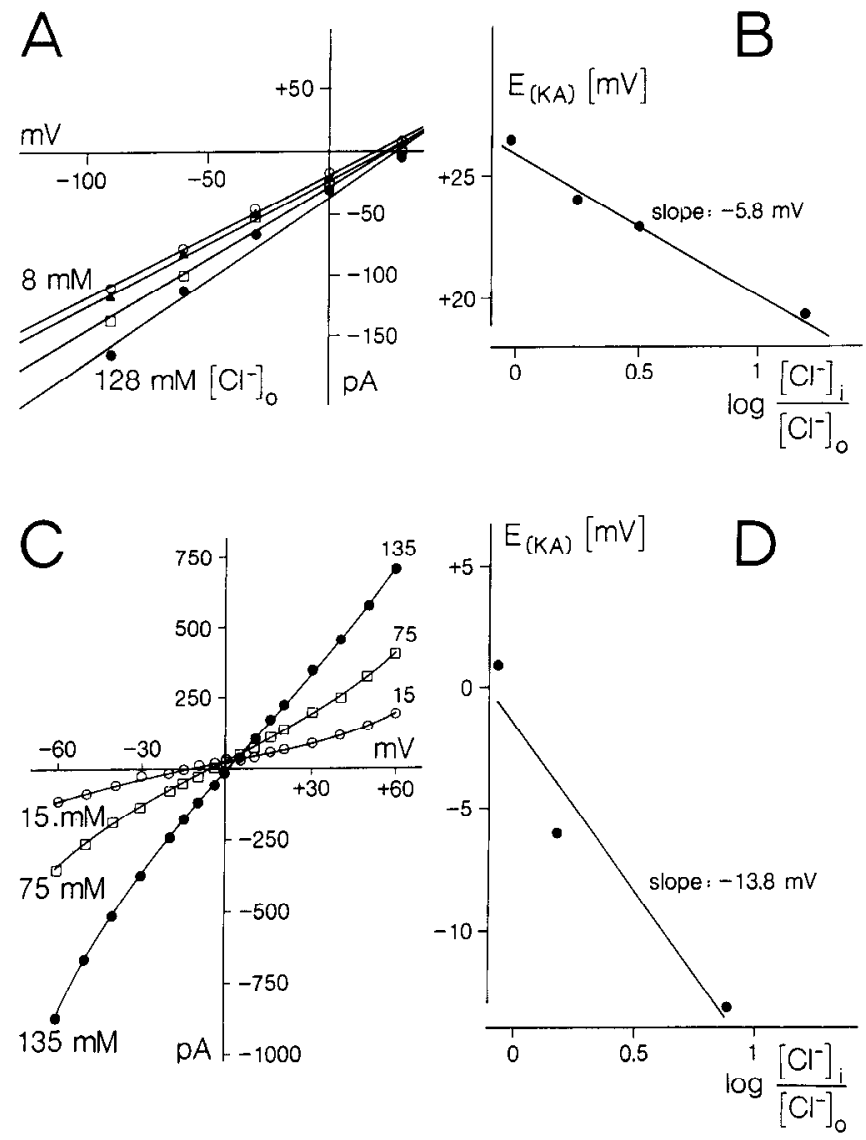

Figure 10. Whole-cell $I-V$ relations and reversal potentials of $I_{(\mathrm{KA})}$ dependent on $\left[\mathrm{Cl}^{-}\right]_{0} . A$ and $B$, Substitution of isethionate for $\mathrm{Cl}^{-}$. Electrode filled with $\mathrm{N}$-methylglucamine. $\left[\mathrm{Cl}^{-}\right]_{0}=120 \mathrm{~mm}$. The levels of $\left[\mathrm{Cl}^{-}\right]_{\mathrm{o}}$ in $A$ were, from top to bottom, $8,38,68$, and $128 \mathrm{~mm}$. Data points are fitted by linear-regression lines. For the line drawn in $B, r=$ 0.991. $C$ and $D$, Substitution of gluconate for $\mathrm{Cl}^{-}$. Electrode filled with CsCl. $\left[\mathrm{Cl}^{-}\right]_{\mathrm{i}}=115 \mathrm{~mm} . C, I-V$ characteristics for 3 different $\left[\mathrm{Cl}^{-}\right]_{\mathrm{o}} . D$, Dependence of reversal potential for $I_{(\mathrm{KA})}$ on the logarithm of transmembrane $\mathrm{Cl}^{-}$gradient. Data points fitted by linear-regression line, with $r=0.968$. Both experiments in $10 \mu \mathrm{M}$ APV.

should sum algebraically. This was not the case. As in retinal neurons (Ishida and Neyton, 1985; Aizenman et al., 1988), currents resulting from simultaneous application of both agonists were smaller than the sum of $I_{(\mathrm{QA})}$ and $I_{(\mathrm{KA})}$. With increasing doses of $Q A$, the response of both $Q A$ and $K A$ approached the amplitude level expected for QA application alone. That QA may, in fact, inducc a complete block of $I_{(\mathrm{KA})}$ is indicated by the absence of a KYN-sensitive current fraction in the compound response to both agonists (Fig. 11A, $d, e$ ). At equimolar QA and $\mathrm{KA}$ concentrations, $I_{(\mathrm{KA})}$ is fully suppressed (Fig. 11Ad). The block of $I_{(\mathrm{KA})}$ by QA was, however, surmounted by increasing the concentrations of KA (Fig. 11, B,C). These results suggest that QA operates as a competitive antagonist of KA and support the previous notion (Monaghan and Cotman, 1982; Monaghan et al., 1983; Fagg and Matus, 1984; Honoré et al., 1986) that QA binds to a KA site. At this site, QA fails to induce a highamplitude, nondesensitizing response, i.e., a response with the characteristic features of $I_{(\mathrm{KA})}$.

\section{Contribution of NMDA, $Q A$, and $K A$ receptors to $\mathrm{I}_{(G l u)}$}

The experiments described above led to the conclusion that, in tectal neurons, NMDA, QA, and KA utilize separate receptors

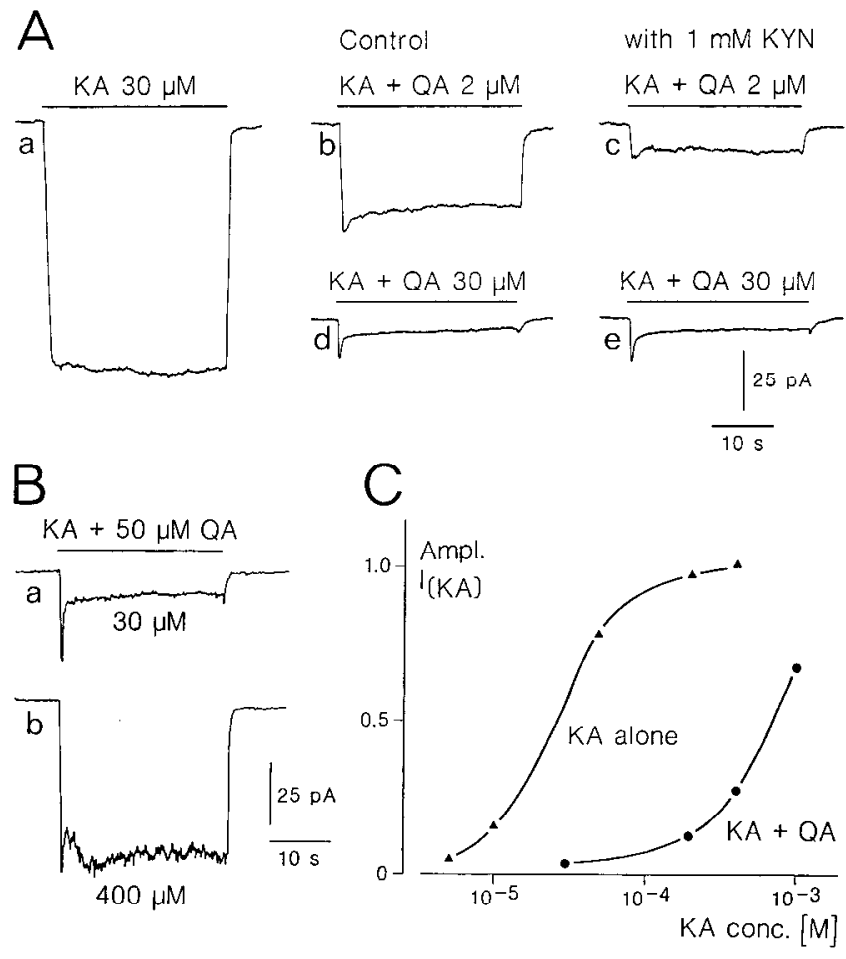

Figure 11. Experiment showing the effect of simultaneous application of QA and KA. A, Demonstration of a KA-receptor-mediated current in the compound response to KA and QA. a, Control with KA alone; $b$ and $d$, response to $\mathrm{KA}$ in the presence of 2 different concentrations of QA (application through a single barrel); $c$ and $e$, Absence of a KYNsensitive component when QA concentration equals KA concentration. Experiment in $10 \mu \mathrm{M}$ APV. $B$, Experiment showing that the QA-induced block of $I_{(\mathrm{KA})}$ can be overcome by raising the concentration of KA. KA concentration indicated below each trace. $C$, Dose-response characteristics for $I_{(\mathrm{KA}+\mathrm{QA})}$. Results from experiment shown in $B$. QA concentration, $50 \mu \mathrm{M}$. Ordinate, normalized current amplitudes measured 20 sec after start of drug application.

or receptor subunits to induce ionic conductance changes. It is not known, however, whether any or all of these receptors are also involved in the current response to the endogenous ligand Glu. Comparing the maximal current amplitudes induced with saturating doses of QA, KA, and Glu, it was noticed that QAactivated currents were generally smaller than $I_{(\mathrm{Glu})}$, whereas $I_{(\mathrm{KA})}$ exceeded $I_{\text {(Glu }}$ in amplitude by 2-3 times. It is therefore conceivable that KA-like effects are suppressed during $I_{\text {(Glu) }}$ as Glu mimics the blocking action of QA at the KA (A3) site. In this case, KYN would have little or no effect on $I_{\text {(Glu), }}$, provided that the NMDA-selective current component is already blocked with $\mathrm{APV}$ or $\mathrm{Mg}^{2+}$. The block of the steady-state component of $I_{(\mathrm{NMDN})}$ was shown to be complete at $V_{h}=-90 \mathrm{mV}$ (Grantyn et al., 1987).

Figure 12 illustrates an experiment in which $\mathrm{Mg}^{2+}$ and $\mathrm{KYN}$ were combined to reveal the A3-mediated fraction of $I_{(\mathrm{Glu})}$. Comparing the current traces at $-90 \mathrm{mV}$ (Fig. 12, B,C, bottom row), it can be seen that with $50 \mu \mathrm{M}$ Glu the contribution of $\mathrm{A} 3$ receptors is indeed small (10\%). However, in experiments with $100 \mu \mathrm{M}$ Glu, the KYN-sensitive component of $I_{\text {(Glu) }}$ increased to $50-80 \%(n=8)$. Similar estimates were achieved using APV as a blocker at $\mathrm{A} 1$ receptors. These experiments indicate that KA receptors do contribute to the compound response to exogenous Glu, although at lower concentrations Glu binds preferentially to NMDA receptors. 
As mentioned, KYN antagonizes not only $I_{(\mathrm{KA})}$, but also $I_{\text {(NMDA) }}$ (Ganong et al., 1983; Elmslie and Yoshikami, 1985; Coleman and Miller, 1986; Huettner and Baughman, 1986). This is confirmed by the results illustrated in Figure $12 D$. A larger portion of $I_{\text {(Glu) }}$ becomes sensitive to KYN when the $\mathrm{Mg}^{2+}$ block is released by depolarization. At $V_{h}=+30 \mathrm{mV}$, the $\mathrm{KYN}$-induced block of $I_{(\mathrm{Glu})}$ equals the combined effect of $\mathrm{Mg}^{2+}$ and $\mathrm{KYN}$ at $-90 \mathrm{mV}$.

\section{Discussion}

\section{Cultured tectal neurons-a substrate for KA?}

When development of tectal neurons takes place in situ, Glu receptors should be functional by P14-21. Intracellular recording from neurons in the isolated rat superficial gray layer showed that nearly all neurons are able to generate EPSPs in response to stimulation of the brachium colliculi 3 weeks after birth ( $R$. Grantyn and R. Schümann, unpublished observations). The pharmacological properties of these EPSPs have, however, remained unexplored. In the present study on cultured neurons, we allowed for 2-3 weeks of in vitro differentiation and found that all neurons from the superficial gray layer are responsive to NMDA, QA, and KA, but not to APB. Close analysis of the agonist-induced effects led us to conclude that 4 distinct receptors for acidic amino acids must exist on these cells. However, it is now well recognized that dissociation procedures, time in vitro, and culture composition may influence the likelihood of revealing one or the other receptor type (see O'Brien and Fischbach, $1986 \mathrm{~b}$, c, for a beautiful demonstration).

We show here that KA-activated currents are larger than $I_{(\mathrm{QA})}$ and $I_{\text {(NMDA) }}$, although binding studies and autoradiographic work on the adult SC has shown that the KA receptor density is very low in this region (London and Coyle, 1979; Unnerstall and Walmsley, 1983). Responsiveness to KA has been studied in rat dorsal root ganglion cells (DRG) of various age (Agrawal and Evans, 1986). These authors suggest that high responsiveness to KA might be a characteristic feature of neonatal neurons. Moreover, in immature DRG neurons, KA receptors are reported to occur on axons (Evans, 1980). Thus, it must be asked to what extent, if any, can $\mathrm{KA}$ receptors be expected to participate in generation of EPSPs.

Convincing evidence favoring a role of $\mathrm{KA}$ receptors in synaptic transmission exists for some retinal and hippocampal connections (Coleman et al., 1986; Cotman et al., 1986; de Montigny et al., 1987; Massey and Miller, 1987). Generally, non-MNDA receptors (both $\mathrm{A} 2$ and $\mathrm{A} 3$ ) are thought to be responsible for the initial fast EPSP. In contrast, slower peak and decay times were seen in EPSPs mediatcd by NMDA rccptors (Dalc and Roberts, 1985; Jahr and Jessel, 1985; Rothman and Samaie, 1985; Nelson et al., 1986; O'Brien and Fischbach, 1986c). In unidentified cortical neurons, stimulation of cultured corticotectal neurons evoked EPSPs with the characteristics of nonNMDA receptors (Huettner and Baughman, 1988). These EPSPs were blocked with $\mathrm{KYN}$, although $\mathrm{KYN}$ failed to discriminate between QA and KA receptors. The high selectivity of $\mathrm{KYN}$ for $\mathrm{KA}$ receptors, as demonstrated in tectal and some retinal (Coleman et al., 1986) neurons, recommends this drug as a tool for further investigation of the role of $\mathrm{KA}$ receptors in primary visual pathways.

We cannot explain why most studies (Ganong et al., 1983; Elmslie and Yoshikami, 1985; Jahr and Jessel, 1985; Huettner and Baughman, 1986; see, however, Gallo et al., 1987) failed to demonstrate a selective block of KA receptors by KYN. A
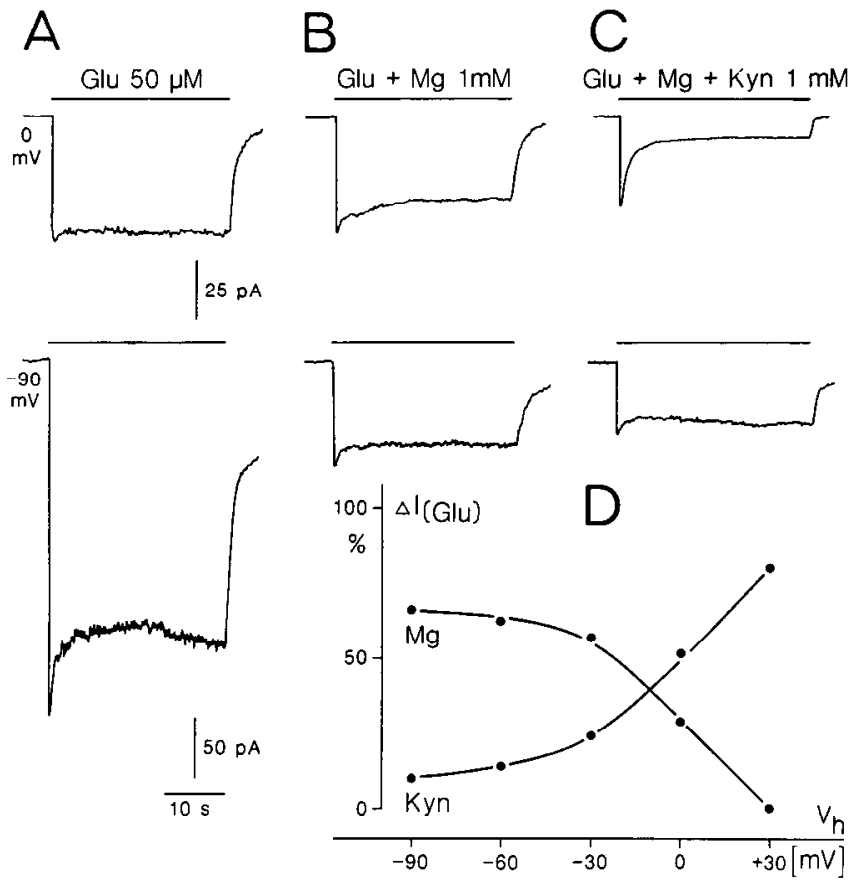

Figure 12. Test to reveal NMDA and KA-receptor-mediated currents in the compound response to Glu. Recordings from a single cell at different holding voltages. Calibration bars for current apply to all records in one horizontal row. $A$, Current response to Glu in a solution without added $\mathrm{Mg}^{2+}, B$, Same response in the presence of $\mathrm{Mg}^{2+}$. Strong reduction of response at $-90 \mathrm{mIV}$. $C$, Same as $B$, but with addition of KYN. D, Fraction of the $\mathrm{Mg}^{2+}$ - and KYN-sensitive current as a percentage of the current amplitude with Glu alone. Amplitudes measured $20 \mathrm{sec}$ after start of Glu application.

high $\mathrm{EC}_{50}$ for $\mathrm{KA}$ may be taken as an indication for the absence of distinct KA receptors in some other preparations (O'Brien and Fischbach, 1986a; O'Dell and Christensen, 1987). Our EC $\mathrm{C}_{50}$ agree well with the estimates of Fagg and Matus (1984), who determined the $K_{\mathrm{i}}$ for Glu displacement in a postsynaptic density (PSD) preparation from rat brain. But these authors reported that KA acts exclusively at a site that binds QA with much higher affinity than $\mathrm{KA}\left(\mathrm{EC}_{50}\right.$ between 0.5 and $\left.10 \mu \mathrm{M}\right)$. They discussed the possibility that a specific KA receptor, as demonstrated by receptor autoradiography (Foster et al., 1981; Monaghan and Cotman, 1982; Unnerstall and Walmsley, 1983; Represa et al., 1987), may exist outside the PSD. As QA caused a complete block of $I_{(\mathrm{KA})}$, it seems unlikely that tectal neurons bear 2 classes of KA receptors capablc of activating a cationic current. However, KA may, in addition to its own site (A3), affect a receptor that promotes a decrease of anionic conductance.

\section{$\mathrm{Ca}^{2+}$ and $\mathrm{Cl}^{-}$dependence of $\mathrm{I}_{(\mathrm{K} 1)}-$ a fourth receptor?}

The demonstration of a pronounced $\mathrm{Cl}^{-}$dependence of $I_{(\mathrm{KA})}$ was an unexpected finding of the present study. A shift of $E_{(\mathrm{KA})}$ towards more negative membrane polentials by reduction of $\left[\mathrm{Cl}^{-}\right]_{\mathrm{O}}$ suggested that $\mathrm{KA}$ decreases a preexisting $\mathrm{Cl}^{-}$conductance $\left(\mathrm{gCl}^{-}\right)$. With our standard intra- and extracellular solutions, this decrease of $\mathrm{gCl}^{-}$would cause an apparent outward current at negative membrane potentials and mask the inward current carried by $\mathrm{Na}^{+}$. The amplitude of the outward component would depend on the background conductance for $\mathrm{Cl}^{-}-$a variable not easily isolated. A decrease of $\mathrm{gCl}^{-}$by $\mathrm{Glu}$ has been observed before (see Miller and Slaughter, 1986), but the identity of un- 
derlying receptors (A4) has not been fully established. Here, we show that KA may be a ligand for the hypothetical A4 site. It is possible that NMDA is also an A4 agonist, because a noticeable outward current remained in some neurons when $I_{(\mathrm{NMDA})}$ was blocked with APV or $\mathrm{Mg}^{2+}$ (Grantyn et al., 1987, Fig. 1D).

The lack of a selective A4-agonist hindered the demonstration of a stimulating effect of higher $\left[\mathrm{Ca}^{2+}\right]_{0}$ at this site (Fagg et al., 1982). In experiments with KA, currents were always reduced by elevation of $\left[\mathrm{Ca}^{2+}\right]_{0}$, as predicted by previous studies of $\mathrm{KA}$ binding (Beaumont et al., 1979; Honoré et al., 1981; Monaghan et al, 1983) and KA-activated ionic conductance (Nowak and Ascher, 1985; Tachibana, 1985).

\section{Possible configurations of acidic amino acid receptors and channels}

There are at least 4 possibilities of receptor and channel arrangement. To explain the lower amplitudes of $I_{(\mathrm{QA})}$ (at saturating agonist concentrations), it could be assumed, first, that fewer receptors and channels were available for QA. The lower number of QA-selective receptors and channels might be a consequence of insufficient expression or rapid desensitization. Second, the number of available QA and KA receptors could be equal, but QA might activate ionic channels with lower opening probability or unitary conductance, e.g., have lower efficacy. Third, several receptors could converge to one and the same channel protein. These receptors must be able to promote different conductance states of the common ionic channel. A configuration such as this is in line with results of single-channel analysis (Cull-Candy and Usowicz, 1987; Jahr and Stevens, 1987), which showed that in any given patch QA-, KA-, and NMDA-activated ionic channels coexisted, and each receptorselective agonist activated all possible conductance levels. Fourth, it has been suggested that QA and KA may share not only their channels but also their receptors (Kiskin et al., 1986; O'Dell and Christensen, 1987). The state of receptors and channels would then be determined by the ligand or any modulatory factor that could make the receptor-channel complex more QAor KA-like.

The first 2 configurations would imply that QA acts as a lowaffinity competitive antagonist at $\mathrm{KYN}$-sensitive $\mathrm{KA}$ receptors and a high-affinity agonist at its own, KYN-insensitive receptor. In this case, the QA-induced block should be overcome by higher concentrations of KA. This is the case in tectal neurons. The fourth configuration (shared channels and receptors) is unlikely, because (1) a selective blocking ligand exists for KA receptors, and (2) KA, but not $\mathrm{QA}$, binding is reduced in high $\left[\mathrm{Ca}^{2+}\right]_{\mathrm{O}}$.

Unfortunately, we are not in the position to either affirm or reject the third possible configuration. Preliminary results from developing tectal neurons indicate that QA and KA sensitivity evolve together, whereas NMDA responses appear after some delay. However, the ratio of maximal $I_{(\mathrm{QA})}$ and $I_{(\mathrm{KA})}$ amplitudes varies largely from cell to cell, indicating that the number or affinity of QA and KA sites is not strictly matched. An uneven distribution of Glu receptors has also been demonstrated in neurons bearing functional synaptic connections (Dale and Roberts, 1985; O'Brien and Fischbach, 1986c; Trussel and Fischbach, 1987). NMDA or non-NMDA receptors could accumulate to give rise to receptor-selective unitary EPSPs (Dale and Robcrts, 1985). As long as more specific arguments are not available, we prefer the most general configuration, the first listed above.
Note added in proof: Recently, new selective non-NMDA receptor antagonists became available from TOCRIS (England). We have tested the compounds 6,7-Dinitroquinoxaline-2,3dione (DNQX) and 6-Cyano-7-nitroquinoxaline-2,3-dione (CNQX) against half-effective concentrations of QA $(0.5 \mu \mathrm{M})$ and KA $(30 \mu \mathrm{M})$. It was found that $5 \mu \mathrm{M}$ DNQX or CNQX reduce both $\mathrm{I}_{(\mathrm{QA})}$ and $\mathrm{I}_{(\mathrm{KA})}$ to about $10 \%$ of the control response. The $\mathrm{IC}_{50}$ of DNQX was about $0.5 \mu \mathrm{M}$ under these conditions. DNQX was slightly more potent than CNQX. We thus confirm that DNQX and CNQX are effective non-NMDA receptor antagonists, which do not, however, discriminate between $\mathrm{A} 2$ and A3 receptor subtypes.

\section{References}

Agrawal, S. G., and R. H. Evans (1986) The primary afferent depolarizing action of kainate in the rat. Br. J. Pharmacol. 87: 345-355.

Aizenman, E., M. P. Frosch, and S. A. Lipton (1988) Responses mediated by excitatory amino acid receptors in solitary retinal ganglion cells from rat. J. Physiol. (Lond.) 396: 75-91.

Anderson, K. J., M. A. Borja, C. W. Cotman, J. R. Moffett, M. A. A. Namboodiri, and J. H. Neale (1987) $\mathrm{N}$-acetylaspartylglutamate identified in the rat retinal ganglion cells and their projections in the brain. Brain Res. 411: 172-177.

Anis, N. A., S. C. Berry, N. R. Burton, and D. Lodge (1983) The dissociative anaesthetics, ketamine and phencyclidine, selectively reduce excitation of central mammalian neurons by N-methyl-aspartate. Br. J. Pharmacol. 79: 565-575.

Ascher, P., and L. Nowak (1987) Electrophysiological studies of NMDA-receptors. Trends Neurosci. 10: 284-288.

Baudry, M., J. Evans, and G. Lynch (1986) Excitatory amino acids inhibit stimulation of phosphatidylinositol metabolism by aminergic agonists in hippocampus. Nature 319: 329-331.

Beaumont, K., Y. Maurin, T. D. Reisine, J. Z. Fields, E. Spokes, E. D. Bird, and H. I. Yamamura (1979) Huntington's disease and its animal model: Alterations in kainic acid binding. Life Sci. 24: 809816.

Biscoe, T. J., R. M. Evans, P. M. Headley, M. R. Martin, and J. C. Watkins (1976) Structure-activity relations of excitatory amino acids on frog and rat spinal neurones. Br. J. Pharmacol. 58: 373-382.

Bridges, R. J., T. J. Hearn, D. T. Monaghan, and C. W. Cotman (1986) A comparison of 2-amino-4-phosphonobutyric acid (AP4) receptors and $\left[{ }^{3} \mathrm{H}\right] \mathrm{AP} 4$ binding sites in the rat brain. Brain Res. 375: 204-209.

Coleman, P. A., and R. F. Miller (1986) Gamma-glutamylaminosulphonate (GAMS) as a specific kainate antagonist in the mudpuppy retina. Soc. Neurosci. Abstr. 12: 958.

Coleman, P. A., S. C. Massey, and R. F. Miller (1986) Kynurenic acid distinguishes kainate and quisqualate receptors in the vertebrate retina. Brain Res. 381: 172-175.

Cotman, C. W., J. A. Flatman, A. H. Ganong, and M. N. Perkins (1986) Effects of excitatory amino acid antagonists on evoked and spontaneous excitatory potentials in guinea-pig hippocampus. J. Physiol. (Lond.) 378: 403-415.

Cull-Candy, S. G., and M. M. Usowicz (1987) Multiple-conductance channels activated by excitatory amino acids in cerebellar neurons. Nature 325: 525-528.

Dale, N., and A. Roberts (1985) Dual component amino-acid-mediated synaptic potentials. Excitatory drive for swimming in Xenopus embryos. J. Physiol. (Lond.) 363: 35-59.

Davies, J., and J. C. Watkins (1981) Differentiation of kainate and quisqualate receptors in the cat spinal cord by selective antagonism with $\gamma$-D(and L)-glutamylglycine. Brain Res. 206: 172-177.

Davies, J., and J. C. Watkins (1985) Depressant actions of $\gamma$-D-glutamylaminomethylsulfonate (GAMS) on amino acid-induced and synaptic excitation in the cat spinal cord. Brain Res. 327: 113-120.

de Montigny, C., M. Weiss, and J. Ouellette (1987) Reduced excitatory effects of kainic acid on rat $\mathrm{CA}^{3}$ hippocampal pyramidal neurons following destruction of the mossy projection with colchicine. Exp. Brain Res. 65: 605-613.

Dudel, J. (1975) Potentiation and desensitization after glutamate induced postsynaptic currents at the crayfish neuromuscular junction. Pfluegers Arch. 356: 317-327.

Elmslie, K. S., and D. Yoshikami (1985) Effects of kynurenate on root 
potentials evoked by synaptic activity and amino acids in the frog spinal cord. Brain Res. 330: 265-272.

Evans, R. H. (1980) Amino acid sensitivity of isolated spinal root fibres from the rat. Br. J. Pharmacol. 70: 53p-54p.

Evans, R. H., A. A. Francis, A. W. Jones, D. A. S. Smith, and J. C. Watkins (1982) The effects of a series of $\Omega$-phosphonic $\alpha$-carboxylic amino acids on electrically evoked and amino acid induced responses in isolated spinal cord preparations. Br. J. Pharmacol. 75: 65-75.

Fagg, G. E., and T. M. I anthorn (1985) $\mathrm{Cl}^{-} / \mathrm{Ca}^{2+}$-dependent L-glutamate binding sites do not correspond to 2-amino-4-phosphonobutanoate-sensitive excitatory amino acid receptors. Br.J.Pharmacol. 86: 43-75.

Fagg, G. E., and A. Matus (1984) Selective association of N-methylaspartate and quisqualate types of L-glutamate receptor with brain postsynaptic densities. Proc. Natl. Acad. Sci. USA 81: 6876-6880.

Fagg, G. E., A. C. Foster, E. E. Mena, and C. W. Cotman (1982) Chloride and calcium ions reveal a pharmacologically distinct population of L-glutamate binding sites in synaptic membranes: Correspondence between biochemical and electrophysiological data. J. Neurosci. 2: 958-965.

Fagg, G. E., A. C. Foster, E. E. Mena, and C. W. Cotman (1983) Chloride and calcium ions separate L-glutamate receptor populations in synaptic membranes. Eur. J. Pharmacol. 88: 105-110.

Feltz, A., and A. Trautman (1982) Desensitization at the frog neuromuscular junction: A biphasic process. J. Physiol. (Lond.) 322:257272.

Fosse, U. M., J. Kolstad, and F. Fonnum (1986) A bioluminiscence method for the measurement of L-glutamate: Applications to the study of changes in the release of L-glutamate from lateral geniculate nucleus and superior colliculus after visual cortex ablation in rats. $\mathbf{J}$. Neurochem. 47: 340-349.

Foster, A. C., and G. E. Fagg (1984) Acidic amino acid binding sites in mammalian neuronal membranes: Their characteristics and relationship to synaptic receptors. Brain Res. Rev. 7: 103-164.

Foster, A. C., E. E. Mena, D. T. Monaghan, and C. W. Cotman (1981) Synaptic localization of kainic acid binding sites. Nature 289: 73-75.

Gallo, V., R. Suergiu, and G. Levi (1987) Functional evaluation of glutamate receptor subtypes in cultured cerebellar neurones and astrocytes. Eur. J. Pharmacol. 138: 293-297.

Ganong, A. H., T. H. Lanthorn, and C. W. Cotman (1983) Kynurenic acid inhibits synaptic and acidic amino acid-induced responses in the rat hippocampus and spinal cord. Brain Res. 273: 170-174.

Grantyn, R., and H. D. Lux (1988) Similarity and mutual exclusion of NMDA- and proton-activated transient $\mathrm{Na}^{+}$-currents in rat tectal neurons. Neurosci. Lett. 89: 198-203.

Grantyn, R., M. Perouansky, H. D. Lux, and J. J. Hablitz (1987) Glutamate-induced ionic currents in cultured neurons from the rat superior colliculus. Brain Res. 420:182-187.

Greenamyre, J. T., A. B. Young, and J. B. Penney (1984) Quantitative autoradiographic distribution of $\mathrm{L}-\left[{ }^{3} \mathrm{H}\right]$ glutamate-binding sites in rat central nervous system. I. Neurosci. 4: 2133-2144.

Hals, G., B. N. Christensen, T. O'Dell, M. Christensen, and R. Shingai (1986) Voltage-clamp analysis of currents produced by glutamate and some glutamate analogues on horizontal cells isolated from the catfish retina. J. Neurophysiol. 56: 19-31.

Hamill, O. P., A. Marty, E. Neher, B. Sakmann, and F. J. Sigworth (1981) Improved patch-clamp techniques for high resolution current recording from cells and cell-free membrane patches. Pfluegers Arch. 391: 85-100.

Honoré, T., J. Lauridsen, and P. Krogsgaard-Larsen (1982) The binding of ${ }^{3} \mathrm{H}$-AMPA, a structural analogue of glutamic acid to rat brain membranes. J. Neurochem. 38: 173-178.

Honoré, T., J. Drejer, and M. Nielsen (1986) Calcium discriminates two $\left[{ }^{3} \mathrm{H}\right]$ kainate binding sites with different molecular target sizes in rat cortex. Neurosci. Lett. 65: 47-52.

Huettner, J. E., and R. W. Baughman (1986) Primary culture of identified neurons from the visual cortex of postnatal rats. J. Neurosci. 6: 3044-3060.

Huettner, J. E., and R. W. Baughman (1988) The pharmacology of synapses formed by identified cortico-collicular neurons in primary cultures of rat visual cortex. J. Neurosci. 8: 160-175.

Ishida, A. T., and J. Neyton (1985) Quisqualate and L-glutamate inhibit retinal horizontal-cell responses to kainate. Proc. Natl. Acad. Sci. 82: 1837-1841.

Jahr, C. E., and T. M. Jessell (1985) Synaptic transmission between dorsal root ganglion and dorsal horn neurons in culture: Antagonism of monosynaptic excitatory postsynaptic potentials and glutamate excitation by kynurenate. J. Neurosci. 5: 2281-2289.

Jahr, C. E., and C. F. Stevens (1987) Glutamate activates multiple single channel conductances in hippocampal neurons. Nature 325 : 522-525.

Katz, B., and S. Thesleff (1957) A study of the desensitization produced by acetylcholine at the motor end-plate. J. Physiol. (Lond.) 138: 6380.

Kemp, J. A., A. C. Foster, and E. H. F. Wong (1987) Non-competitive antagonists of excitatory amino acid receptors. Trends Neurosci. 10: 294-298.

Kessler, M., M. Baudry, and G. Lynch (1987a) Use of cystine to distinguish glutamate binding from glutamate sequestration. Neurosci. Lett. 81: 221-226.

Kessler, M., G. Petersen, H. M. Vu, M. Baudry, and G. Lynch (1987b) L-phenylalanyl-L-glutamate-stimulated, chloride-dependent glutamate binding represents glutamate sequestration mediated by an exchange system. J. Neurochem. 48: 1191-1200.

Kiskin, N. I., O. A. Krishtal, and A. Y. Tsyndrenko (1986) Excitatory amino acid receptors in hippocampal neurons: Kainate fails to desensitize them. Neurosci. Lett. 63: 225-230.

Konnerth, A., H. D. Lux, and M. Morad (1987) Proton-induced transformation of calcium channel in chick dorsal root ganglion cells. J. Physiol. (Lond.) 386: 603-633.

London, E. D., and J. T. Coyle (1979) Specific binding of $\left[{ }^{3} \mathrm{H}\right] \mathrm{kainic}$ acid to receptor sites in rat brain. Mol. Pharmacol. 15: 492-505.

MacDermott, A. B., and N. Dale (1987) Receptors, ion channels and synaptic potentials underlying the integrative actions of excitatory amino acids. Trends Neurosci. 10: 280-284.

Magazanik, L. G., and F. Vyskočil (1973) Desensitization at the motor end-plate. In Drug Receptors, H. P. Rang, ed., pp. 105-1 19, Macmillan, London.

Massey, S. C., and R. F. Miller (1987) Excitatory amino acid receptors of rod- and cone-driven horizontal cells in the rabbit retina. J. Neurophysiol. 57: 645-659.

Mayer, M. L., and G. L. Westbrook (1984) Mixed-agonist action of excitatory amino acids on mouse spinal cord neurones under voltage clamp. J. Physiol. (Lond.) 354: 29-53.

Mayer, M. L., and G. L. Westbrook (1987) The physiology of excitatory amino acids in the vertebrate central nervous system. Prog. Neurobiol. 28: 197-276.

Mayer, M. L., G. L. Westbrook, and P. B. Guthrie (1984) Voltagedependent block by $\mathrm{Mg}^{2+}$ of NMDA responses in spinal cord neurones. Nature 309: 261-263.

McCaslin, P. P., and W. W. Morgan (1987) Cultured cerebellar cells as an in vitro model of excitatory amino acid receptor function. Brain Res. 417: 380-384.

McLennan, H., and D. Lodge (1979) The antagonism of amino acidinduced excitation of spinal neurones in the cat. Brain Res. 169:8390

Mena, E. E., M. J. Pagnozzi, and M. F. Gullak (1986) Characterization of L-glutamate binding sites in rat spinal cord synaptic membranes: Evidence for multiple chloride ion-dependent sites. J. Neurochem. 47: 1052-1060.

Miljkovic, Z., and J. F. MacDonald (1986) Voltage-dependent block of excitatory amino acid currents by pentobarbital. Brain Res. 376: 396-399.

Miller, R. F., and R. F. Dacheux (1976) Synaptic organization and ionic bases of on and off channels in mudpuppy retina. J. Gen. Physiol. 67: 639-659.

Monaghan, D. T., and C. W. Cotman (1982) The distribution of $\left[{ }^{3} \mathrm{H}\right] \mathrm{kainic}$ acid binding sites in rat CNS as determined by autoradiography. Brain Res. 252: 91-100.

Monaghan, D. T., and C. W. Cotman (1985) Distribution of N-methylD-aspartate-sensitive $\mathbf{L}-\left[{ }^{3} \mathrm{H}\right]$ glutamate binding sites in rat brain. $\mathrm{J}$. Neurosci. 5: 2909-2919.

Monaghan, D. T., V. R. Holets, D. W. Toy, and C. W. Cotman (1983) Anatomical distributions of four pharmacologically distinct ${ }^{3} \mathrm{H}-\mathrm{L}$ glutamate binding sites. Nature 306: 176-179.

Nelson, P. G., R. Y. K. Pun, and G. L. Westbrook (1986) Synaptic excitation in cultures of mouse spinal cord neurons: Receptor pharmacology and behavior of synaptic currents. J. Physiol. (Lond.) 372: 169-182.

Nicoletti, F., M. J. Iadarola, J. T. Wroblewski, and E. Costa (1986) 
Excitatory amino acid recognition sites coupled with inositol phospholipid metabolism: Developmental changes and interaction with $\alpha_{1}$-adrenoceptors. Proc. Natl. Acad. Sci. USA 83: 1931-1935.

Novelli, A., F. Nicoletti, J. T. Wroblewski, H. Alho, E. Costa, and A. Guidotti (1987) Excitatory amino acid receptors coupled with guanylate cyclase in primary cultures of cerebellar granule cells. J. Neurosci. 7: 40-47.

Nowak, L. M., and P. Ascher (1985) Divalent cation effects on NMDAactivated channels can be described as $\mathrm{Mg}$-like or Ca-like. Soc. Neurosci. Abstr. 11: 953

O’Brien, R. J., and G. D. Fischbach (1986a) Characterization of excitatory amino acid receptors expressed by embryonic chick motoneurons in vitro. J. Neurosci. 6: 3275-3283.

O'Brien, R. J., and G. D. Fischbach (1986b) Excitatory synaptic transmission between interneurons and motoneurons in chick spinal cord cell cultures. J. Neurosci. 6: 3284-3289.

O'Brien, R. J., and G. D. Fischbach (1986c) Modulation of embryonic chick motoneuron glutamate sensitivity by interneurons and agonists. J. Neurosci. 6: 3290-3296.

O'Dell, T. J., and B. N. Christensen (1987) Interaction of excitatory amino acids at a single non-NMDA type receptor in isolated catfish horizontal cells. Soc. Neurosci. Abstr. 13: 384.

Olson, J. M. M., J. T. Greenamyre, J. B. Penney, and A. B. Young (1987) Autoradiographic localization of cerebellar excitatory amino acid binding sites in the mouse. Neuroscience 22: 913-923.

Pin, J. P., J. Bockaert, and M. Récasens (1984) The $\mathrm{Ca}^{2}+/ \mathrm{Cl}^{-}$dependent $\left.\mathbf{L}{ }^{3} \mathrm{H}\right]$ glutamate binding: A new receptor or a particular transport process? FEBS Lett. 175: 31-36.

Represa, A., E. Tremblay, and Y. Ben-Ari (1987) Kainate binding sites in the hippocampal mossy fibers: Localization and plasticity. Neuroscience 20:739-748.
Rothman, S. M., and M. Samaie (1985) Physiology of excitatory synaptic transmission in cultures of dissociated rat hippocampus. J. Neurophysiol. 54: 701-712.

Sladeczek, F., J. P. Pin, M. Récasens, J. Bockaert, and S. Weiss (1985) Glutamate stimulates inositol phosphate formation in striatal neurons. Nature 317: 717-719.

Slaughter, M. M., and R. F. Miller (1981) 2-Amino-4-phosphonobutyric acid: A new pharmacological tool for retina research. Science 211: 182-185.

Sugiyama, H., I. Ito, and C. Hirono (1987) A new type of glutamate receptor linked to inositol phospholipid metabolism. Nature 325: 531-533.

Tachibana, M. (1985) Permeability changes induced by L-glutamate in solitary retinal horizontal cells isolated from Carassius auratus. J. Physiol. (Lond.) 358: 153-167.

Unnerstall, J. R., and J. K. Wamsley (1983) Autoradiographic localization of high-affinity $\left[{ }^{3} \mathrm{H}\right] \mathrm{kainic}$ acid binding sites in the rat forebrain. Eur. J. Pharmacol. 86: 361-371.

Vlachová, V., L. Vyklický, L. Vyklický, Jr., and F. Vyskočil (1987) The action of excitatory amino acids on chick spinal cord neurones in culture. J. Physiol. (Lond.) 386: 425-438.

Vyklický, L., L. Vyklický, Jr., F. Vyskočil, V. Vlachová, E. Ujec, and J. Michl (1986) Evidence that excitatory amino acids not only activate the receptor channel complex but also lead to use-dependent block. Brain Res. 363: 148-151.

Wong, E. H. F., J. A. Kemp, T. Priestley, A. R. Knight, G. N. Woodruff, and $\mathrm{L}$. L. Iversen (1986) The anticonvulsant MK 801 is a potent N-methyl-D-aspartate antagonist. Proc. Natl. Acad. Sci. USA 83: 7104-7108. 